\title{
Spatial and temporal patterns in snow accumulation, western Dronning Maud Land, Antarctica
}

\author{
ELISABETH ISAKSSON AND WIBJÖRN KARLÉN \\ Department of Physical Geography, Stockholm University, S-106 91 Stockholm, Sweden
}

\begin{abstract}
During the Swedish Antarctic Expedition to Dronning Maud Land, Antarctica, 1988-89 the net accumulation was estimated for an area from the coast to about $400 \mathrm{~km}$ inland. Stake measurements were used to obtain the spatial variability and firn cores were used for the temporal variability. The mean annual accumulation for the period 1976-88 is about $0.4 \mathrm{~m}$ w.e. for Riiser-Larsenisen and about $0.3 \mathrm{~m}$ w.e. for the area above the grounding line. The accumulation rate at higher altitudes, $>2500 \mathrm{~m}$ a.s.l., is about $0.1 \mathrm{~m}$ w.e. for $1955-88$. One record from the ice shelf covers the period 1957-88, and suggests an increase in accumulation of about $12 \%$. Between 1976 and 1988, the accumulation has decreased by about $50 \%$, most likely due to lower temperatures as suggested by the temperature record from Halley.
\end{abstract}

\section{INTRODUCTION}

The present mass-balance status of the Antarctic ice sheet is still unknown despite increasing field observations in combination with computer modelling. We still do not know whether this ice sheet is in balance with the present climate. Together, the Antarctic and the Greenland ice sheets contain $99 \%$ of the ice on Earth (Drewry, 1983), which is equivalent to a sea-level rise of about $65 \mathrm{~m}$ (Oerlemans and Van der Veen, 1984). It is uncertain what would happen to these ice sheets if the world's climate were to undergo warming, because an increase in temperature will lead to an increase in precipitation as well as enhanced ablation (e.g. Oerlemans, 1982; Oerlemans and Van der Veen, 1984; Robin, 1988; Zwally, 1989).

The Swedish Antarctic Research Program (SWEDARP) has recently conducted glaciological research in western Dronning Maud Land, East Antarctica (Fig. 1), a relatively unexplored part of the Antarctic ice sheet. The overall aim of the glaciological project is to determine whether this small ice-drainage area of the East Antarctic ice sheet is in balance with the present climate. A large part of this ice-drainage system is marinebased (Hoppe and Thyssen, 1988; Holmlund, unpublished data), which may accentuate the sensitivity of this area to changes in climatic conditions. The part of the project presented in this paper concentrates on the surface-accumulation rate in this area.

In order to establish the spatial accumulation pattern, the accumulation rate was measured along a $350 \mathrm{~km}$ long stake traverse from the coast (Fig. 2) for two accumulation years (Holmlund and others, 1989; Näslund and others, 1991). $10 \mathrm{~m}$ deep firn cores were collected along this traverse for detecting any temporal variations in net accumulation. The depth and age relationship of the cores was established using oxygen-isotope stratigraphy and, in one case, $\beta$ activity. Results concerning the present surface-accumulation rate and spatial pattern, changes in accumulation rate over the last decades and the relationship between accumulation and temperature are presented, and discussed in this paper. The climatic implications from the oxygen-isotope study will be presented in another paper by the same authors.

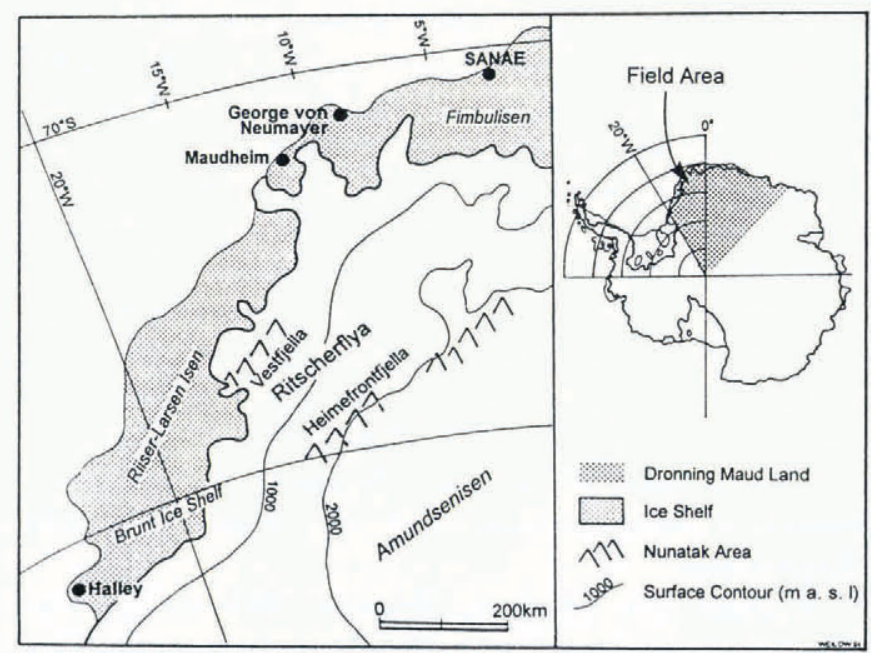

Fig. 1. The location of the field area on the Antarctic ice sheet together with nearby locations mentioned in the text and in Table 1. 


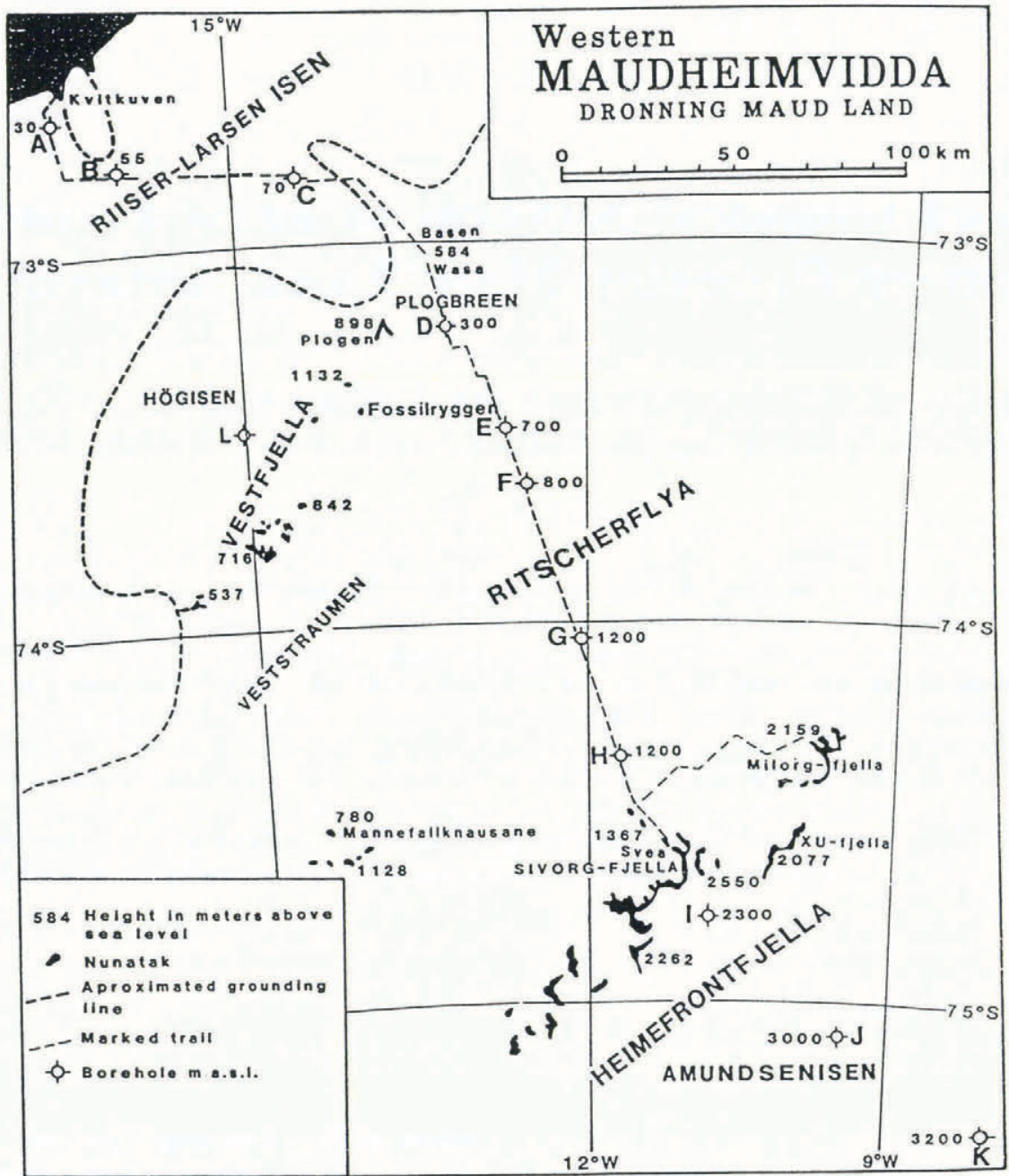

Fig. 2. A detailed map of the part of Dronning Maud Land where the Swedish Antarctic Research Program has its activities. Geographical names mentioned in the text as well as the main stake traverse and the firn-core locations $(A-L)$ are included.

\section{DESGRIPTION OF THE FIELD AREA}

\section{Morphology}

Riiser-Larsenisen is one of many small ice shelves along the margin of Antarctica with a width between 50 and $150 \mathrm{~km}$. The grounding line is situated close to the nunatak area, Vestfjella, which is almost parallel to the coast. Few peaks in this basaltic mountain range exceed $1000 \mathrm{~m}$ a.s.l. and some of them barely project above the ice sheet. In the vicinity of the grounding line, the ice surface begins to rise from roughly $300 \mathrm{~m}$ a.s.l. to $1300 \mathrm{~m}$ a.s.l. close to the nunatak area farther inland, Heimefrontfjella. The ice sheet between these two nunatak areas, Ritscherflya, has an undulating surface rising towards the Heimefrontfjella mountain range which has peaks reaching up to about $2700 \mathrm{~m}$ a.s.l. damming the upstream ice. There is about $500 \mathrm{~m}$ of elevation change between the upstream side of Heimefrontfjella (Amundsenisen) and the downstream side (Ritscherflya).

A small local ice dome, Högisen ( $900 \mathrm{~m}$ a.s.l.), rises about $250 \mathrm{~m}$ above the surrounding ice sheet to the east and around $700 \mathrm{~m}$ above Riiser-Larsenisen to the west. Two small ice streams, Veststraumen and Plogbreen, are situated on each side of this ice dome.

\section{Present climate}

During the austral summer of 1988-89, an automatic weather station was established at the Finnish research station Aboa situated on the nunatak Basen ( $400 \mathrm{~m}$ a.s.l.) in the Vestfjella mountains (Fig. 2). The mean annual temperature for 1989 was approximately $-16^{\circ} \mathrm{C}$ (data from Finnish Antarctic Expedition). Another automatic weather station in Sivorgfjella (Heimefrontfjella), situated

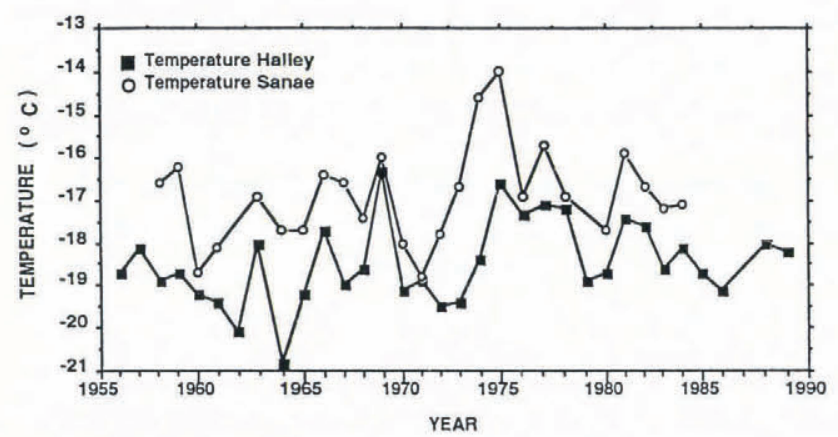

Fig. 3. Mean annual temperatures from Halley and SANAE. Data from Halley were obtained from the British Antarctic Survey and data from SANAE from Fones and Limbert (1987). 
at $1200 \mathrm{~m}$ a.s.l., shows an annual average temperature of $-18.2^{\circ} \mathrm{C}$ for 1988 (Jonsson, unpublished data). However, the latter station is situated in a blue-ice area close to the nunataks and is therefore not necessarily representative of the larger area.

At Halley Station (Fig. 1), $500 \mathrm{~km}$ southwest of the field area, the temperature has been recorded since 1956 (Fig. 3) (data obtained directly from the British Antarctic Survey). Another nearby temperature record comes from SANAE Station (Fig. 1), about $500 \mathrm{~km}$ northeast of the Vestfjella area, where records extend back to 1957 (Fig. 3) (Jones and Limbert, 1987). Complete annual data series are only available up to 1984 from this station.

Katabatic winds dominate the wind pattern in most of the Antarctic continent (Parish and Bromwich, 1987); in this area of Dronning Maud Land they come from the east-southeast.

\section{PREVIOUS GLACIOLOGICAL WORK IN THIS AREA}

\section{Accumulation}

All mass-balance calculations available from western Dronning Maud Land are compiled in Table 1. The earliest scientific work in this part of Dronning Maud Land was done during the Norwegian-British-Swedish Antarctic Expedition, 1949-52. At the coastal station, Maudheim (Fig. 1), the average accumulation was calculated from a combination of stake measurements and stratigraphic studies (Schytt, 1958). From a $300 \mathrm{~km}$ traverse inland, the mass-balance values were found to be of the same order of magnitude as on the ice shelf.

Table 1. Compilation of accumulation measurements available for western Dronning Maud Land

Location

\section{Period Accumul- Reference ation rate}

cm w.e.
When the station was revisited in 1960, the average mass balance between 1952 and 1960 showed a slight increase (Swithinbank, 1962). Further to the east, on Fimbulisen (Fig. 1), the mass balance was found to be somewhat higher than at Maudheim during the same time periods (Lunde, 1961). The accumulation rate at Georg von Neumayer, between 1964 and 1979, was estimated using tritium analysis (Reinwarth and others, 1982) and with $\delta^{18} \mathrm{O}$ for 1977-81 (Reinwarth and others, 1985).

Accumulation studies have been carried out on RiiserLarsenisen using both stake measurements and oxygenisotope stratigraphy on firn cores (Lunde, 1961; Repp, 1978; Gjessing and Wold, 1986; Orheim and others, 1986). Both stratigraphic studies (Repp, 1978) and stake measurements (Gjessing and Wold, 1986) show higher accumulation values for the period 1975-78 than is suggested by the oxygen-isotope stratigraphy from the same area (Orheim and others, 1986).

The summer surface is generally poorly developed at Riiser-Larsenisen and, therefore, accumulation estimates from pit studies are not reliable. Melting occurs in the snow during the summer season but it is insufficient to penetrate a complete annual layer (Gjessing and Wold, 1986).

Before the Swedish Antarctic Expedition of 1988-89, no accumulation measurements had been made above the grounding line in the Vestfjella area.

\section{Ice velocity}

Ice-velocity measurements show that the ice velocity on Ritscherflya is about 10 mear $^{-1}$ (Holmlund, unpublished data). The ice velocity increases to around 30 mear $^{-1}$ at the grounding line and the highest velocity, $130 \mathrm{~m} \mathrm{year}^{-1}$, is found about $10 \mathrm{~km}$ downstream from the grounding line. Near the ice front, the velocity is about 110 m year $^{-1}$ (Gjessing and Wold, 1986).

The Heimefrontfjella mountain range dams the inland-ice flow and the ice is channelled through the mountains in smaller outlet glaciers; most of the ice is drained through Veststraumen and only a small amount through Plogbreen (Fig. 2). Ice-velocity measurements at Plogbreen showed a velocity close to $100 \mathrm{myear}^{-1}$ (Holmlund and others, 1989). At present, ice velocities at Veststraumen are unknown but they will be determined in the future as part of SWEDARP.

\section{METHODS}

The following maps cover the field area: Ritscherhochland SS 28-30 1:100000 (1986), published in Germany by the Institut für Angewandte Geodäsie, and on Norsk Polarinstitutt's maps: Vestfjella Vest B7 (1972); Vestfjella Aust (1972), Vestfjella Nord D8 (1988) and Heimefrontfjella Sör D9 (1988) at a scale of $1: 25000$.

\section{Field}

\section{Stake measurements}

The net accumulation is calculated using the stake-height differences between observations multiplied by the snow density from a nearby pit. This method was described by 
Østrem and Stanley (1969). The snow density was estimated using a steel snow sampler with a volume of $1 \mathrm{dm}^{3}$ and an electronic scale (A \& D Company EW Series 3000B).

The compaction of the snow was not taken into account when calculating the accumulation, since we were not certain whether the anchoring position of the stake was fixed or if it had changed with time. However, the snow compaction has often been found to be so small that it can be neglected (Lorius, 1983).

\section{Firn cores}

A PICO hand-auger corer, with a diameter of $7.5 \mathrm{~cm}$ (Koci and Kuivinen, 1984), was used to obtain $10 \mathrm{~m}$ deep firn cores. The uppermost metre was sampled in a snow pit, as the core broke apart due to its low density. The density of the snow in the core was determined by measuring each part of the core and weighing it on an electronic scale. Each core section was packed in a plastic bag until it was possible to cut it into smaller segments. This was done in a tent to avoid direct sunlight and wind. The cores were cut so that at least 10-20 samples per annual layer could be obtained (Peel and Clausen, 1982). Based on previous work in the area (Orheim and others, 1986), $5 \mathrm{~cm}$ samples were considered to be appropriate for the coastal sites, and the sample size was successively decreased to $1.5 \mathrm{~cm}$ at the Amundsenisen site. The samples were packed in labelled plastic bags and kept frozen for further transport to the laboratory.

The temperature was measured with a Fluke 51 digital thermometer at $10 \mathrm{~m}$ depth in the boreholes. The thermometer was placed in the hole until it showed a stable value. This commonly took $0.5-1 \mathrm{~h}$. The temperature obtained is supposed to be well correlated with the average annual temperature above the inversion layer at the location (Loewe, 1970). The temperature measurements are necessary for calibrating the $\delta^{18} \mathrm{O}$ stratigraphy in the firn cores with the mean annual temperature (Dansgaard and others, 1973).

The exact position of each drill site was determined by GPS (Magnavox MX-4400).

\section{Laboratory}

\section{Oxygen isotopes}

Snow samples were transferred from plastic bags to $25 \mathrm{ml}$ plastic bottles as soon as possible after they were melted. They were frozen again until analysed.

All samples, except for core C, were analysed for oxygen isotopes on the mass spectrometer at the Geophysical Isotope Laboratory, University of Copenhagen. The analysis of firn core $\mathrm{C}$ was carried out by the authors at the Department of Hydrology, University of Uppsala, on a Finnigan Mat mass spectrometer.

\section{$\beta$ activity}

Marked peaks in $\beta$ activity, produced by thermonuclear tests, are frequently used as reference horizons all over Antarctica (e.g. Mosley-Thompson and others, 1985; Aristarain and others, 1986; Whillans and Bindschadler, 1988). In this work, $\beta$ activity was measured in one core $(\mathrm{J})$ in which the oxygen-isotope stratigraphy was not sufficiently clear for an annual resolution. The remnant water from the isotope analyses was used for this purpose. The analyses were performed under the supervision of $\mathrm{Dr}$ E. Mosley-Thompson.

\section{RESULTS}

\section{Accumulation from stake measurements}

The snow-accumulation measurements obtained from stakes along the traverses are summarized in Table 2. The spacing between the stakes is $2 \mathrm{~km}$ over the ice shelf and $0.5 \mathrm{~km}$ for the remainder of the traverse. The stakes were measured during 1988 and 1989. The total number of stakes is 529 .

Table 2. Accumulation data for stake traverse over RiiserLarsenisen and Ritscherflya. The standard deviations of the accumulation measurements are in parentheses

$\begin{array}{ccccc}\text { Traverse } & \begin{array}{c}\text { Accumulation } \\ 1988^{1}\end{array} & \begin{array}{l}\text { Mean } \\ \text { density }\end{array} & \begin{array}{c}\text { Accumulation } \\ 1989^{2}\end{array} & \begin{array}{l}\text { Mean } \\ \text { density }\end{array} \\ & \text { cmw.e. } & \mathrm{kg} \mathrm{m}^{-3} & \mathrm{~cm} \text { w.e. } & \mathrm{kg} \mathrm{m}^{-3}\end{array}$

Basen-Svea 11.3 (7.8) $364 \quad 22.4$ (10.2)

(Ritscherflya)

Coast-Basen

(Riiser-Larsenisen)

${ }^{1}$ All the stake and density measurements from 1988 have been published in Holmlund and others (1989).

2 All the stake and density measurements from 1989 have been published in Näslund and others (1991).

So far, only 1 year of accumulation measurements is available for the whole traverse (Fig. 4, Table 2) but, for the part of the stake traverse over Ritscherflya, the 1988 accumulation measurements are also available (Fig. 5, Table 2). The density was obtained from snow pits at firn-

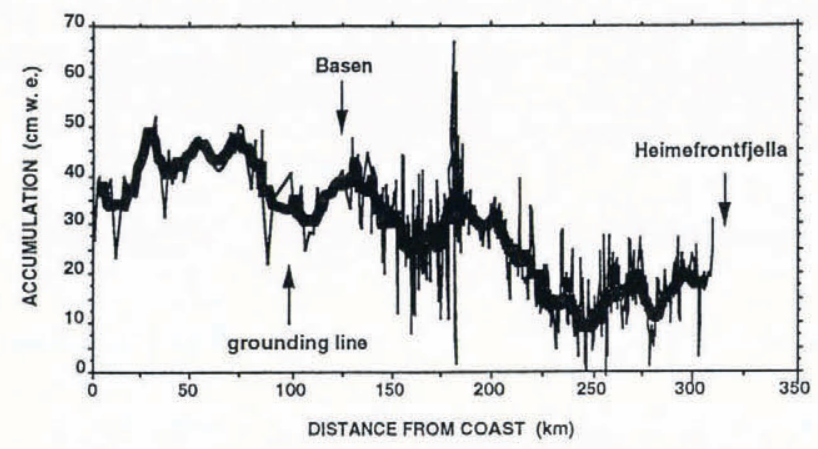

Fig. 4. The 1989 surface accumulation along the coastinland traverse ( $\mathcal{N a}$ slund and others, 1991). In the area from the coast to Basen, the spacing between the stakes is $2 \mathrm{~km}$ and, between Basen and Heimefrontfjella, it is $0.5 \mathrm{~km}$. The thick line is the running mean over $10 \mathrm{~km}$. The approximate locations of the grounding line, Basen and Heimefrontfjella are indicated by arrows. 


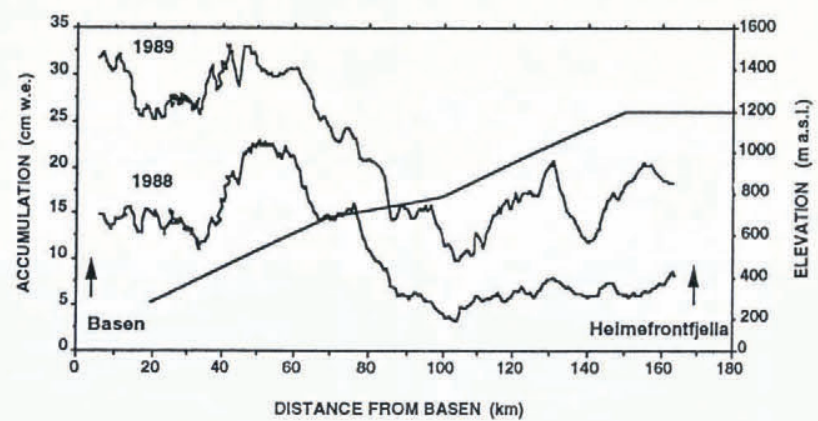

Fig. 5. Accumulation along the Basen (Vestfjella)Heimefrontfjella stake traverse during 1988 (Holmlund and others, 1989) and 1989 (Näslund and others, 1991). Both curves are running means over $10 \mathrm{~km}$ (20 stakes). The approximate locations of Basen and Heimefrontfjella are indicated by arrows. The thin line is the elevation along the stake line. The elevation measurements are based on GPS measurements at five core locations.

core locations A-H (Fig. 2). The accumulation was calculated for 1988 using the mean densities in the uppermost $25 \mathrm{~cm}$ of snow pits at the firn-core locations $\mathrm{D}-\mathrm{H}$.

\section{Firn cores}

\section{Dating}

Before the isotopic stratigraphy can be translated into an accumulation record, the $\delta^{18} \mathrm{O}$ must be dated. Core $\mathrm{B}$ was not analysed for oxygen isotopes and the material was retained for ${ }^{10} \mathrm{Be}$ analysis (AlDahan and others, 1990). The mean $\delta^{18} \mathrm{O}$, the total number of samples analysed and the position of each core are listed in Table 3.

\section{Table 3. Positions of firn cores}

\begin{tabular}{|c|c|c|c|c|}
\hline $\begin{array}{l}\text { Core } \\
\text { location }\end{array}$ & Lat. long. & Elevation & $\begin{array}{l}\text { Distance from } \\
\text { coast }\end{array}$ & $\begin{array}{c}10 \mathrm{~m} \\
\text { temperature }\end{array}$ \\
\hline & & m a.s.l. & $\mathrm{km}$ & \\
\hline
\end{tabular}

\begin{tabular}{|c|c|c|c|c|}
\hline \multirow[t]{2}{*}{ A } & $72^{\circ} 39.251^{\prime} \mathrm{S}$ & $<100$ & 13 & -16.7 \\
\hline & $16^{\circ} 38.728^{\prime} \mathrm{W}$ & & & \\
\hline \multirow[t]{2}{*}{ B } & $72^{\circ} 44.111^{\prime} \mathrm{S}$ & $<100$ & 45 & -18.3 \\
\hline & $15^{\circ} 58.323^{\prime} \mathrm{W}$ & & & \\
\hline \multirow[t]{2}{*}{$\mathrm{C}$} & $72^{\circ} 45.72^{\prime} \mathrm{S}$ & $<100$ & 90 & -18.5 \\
\hline & $14^{\circ} 35.39^{\prime} \mathrm{W}$ & & & \\
\hline \multirow[t]{2}{*}{ D } & $73^{\circ} 27.392^{\prime} \mathrm{S}$ & 300 & 120 & -18.5 \\
\hline & $12^{\circ} 33.454^{\prime} \mathrm{W}$ & & & \\
\hline \multirow[t]{2}{*}{$\mathrm{E}$} & $73^{\circ} 35.634^{\prime} \mathrm{S}$ & 700 & 150 & -21 \\
\hline & $12^{\circ} 25.607^{\prime} \mathrm{W}$ & & & \\
\hline \multirow[t]{2}{*}{$\mathrm{F}$} & $73^{\circ} 48.946^{\prime} \mathrm{S}$ & 800 & 170 & -18.1 \\
\hline & $12^{\circ} 12.614^{\prime} \mathrm{W}$ & & & \\
\hline \multirow[t]{2}{*}{ G } & $74^{\circ} 00.838^{\prime} \mathrm{S}$ & 1200 & 200 & -21.4 \\
\hline & $12^{\circ} 00.989^{\prime} \mathrm{W}$ & & & \\
\hline \multirow[t]{2}{*}{$\mathrm{H}$} & $74^{\circ} 21.082^{\prime} \mathrm{S}$ & 1200 & 260 & -20 \\
\hline & $11^{\circ} 43.345^{\prime} \mathrm{W}$ & & & \\
\hline \multirow[t]{2}{*}{$\mathrm{J}$} & $75^{\circ} 04.78^{\prime} \mathrm{S}$ & 3000 & 400 & -28.3 \\
\hline & $09^{\circ} 32.30^{\prime} \mathrm{W}$ & & & \\
\hline
\end{tabular}

The isotopic stratigraphies in the cores from RiiserLarsenisen (Fig. 6a-b) show well-pronounced seasonal variation. Differences of $10 \%$ between summer and winter surfaces are common. Also, the seasonal stratigraphies in cores from between the grounding line and Heimefrontfjella (Fig. 6c-g) are sufficiently clear to allow recognition of annual accumulation. This is not the case with the core from Amundsenisen (Fig. 6h), which shows a more ambiguous isotope stratigraphy.

We believe the stratigraphies could be established because of a distinct annual variation in $\delta^{18} \mathrm{O}$. Comparing patterns in $\delta^{18} \mathrm{O}$ variations between localities yielded further support for this conclusion. A time-scale was assigned to each core by comparing the seasonal $\delta^{18} \mathrm{O}$ variations in cores A, C-H, seeking similar patterns. To make this approach possible, it was assumed that no annual accumulation layers were missing at RiiserLarsenisen (cores $\mathrm{A}$ and $\mathrm{C}$ ), where the accumulation was high. These cores were used to identify annual layers in the cores with low accumulation farther inland. Each of the $\delta^{18} \mathrm{O}$ versus depth relationships was then compared with the $\delta^{18} \mathrm{O}$ record in precipitation from Halley (International Atomic Energy Agency, 1975, 1979, 1984, 1990). Similar patterns and particularly marked peaks in the $\delta^{18} \mathrm{O}$ stratigraphies were used as stratigraphic markers. However, a detailed correlation could not be performed because the distribution of precipitation during the year is known in the Halley $\delta^{18} \mathrm{O}$ record but not in the firn-core records. Another problem is of course the geographical distance between the sites of the records.

The summer surface (the most positive $\delta^{18} \mathrm{O}$ ) is used as the annual stratigraphic marker. In this way, more than 15 years can be identified. The adapted time-scales for cores A, C, D, E, F, G and $\mathrm{H}$ are presented in Figure $6 \mathrm{a}-\mathrm{g}$. Because the summer surface of $1988-89$ in core C was not well developed at the time of sampling, the accumulation for 1988 could not be calculated for this particular core.

As already mentioned, the oxygen-isotope stratigraphy for core $\mathrm{J}$ is more complicated and the same dating technique was therefore not possible. Nevertheless, because an additional independent parameter for the construction of the time-scale ( $\beta$ activity) was measured in core $\mathrm{J}$, this core could be used for accumulation calculations. Despite the alternative dating method for core $\mathrm{J}$, the oxygen-isotope stratigraphy is still difficult to interpret.

\section{Accumulation calculations}

The annual accumulation rates for each core with a dated stratigraphy are listed in Table 4.

The mean for the periods 1975-79, 1980-84 and 1985-88 are calculated as well as the mean for the whole period that each core represents. To enable a direct comparison between the cores, the accumulation rate for the period of 1976-88 is calculated. The mean annual accumulation for Riiser-Larsenisen (cores A and C) during $1976-88$ is about $40 \mathrm{~cm}$ w.e. and about $30 \mathrm{~cm}$ w.e. for Ritscherflya (cores D-H).

The annual accumulation values for cores A, C-H, during the period covered in each core, are plotted in Figure $7 \mathrm{a}-\mathrm{g}$. To avoid some of the local variability, the 

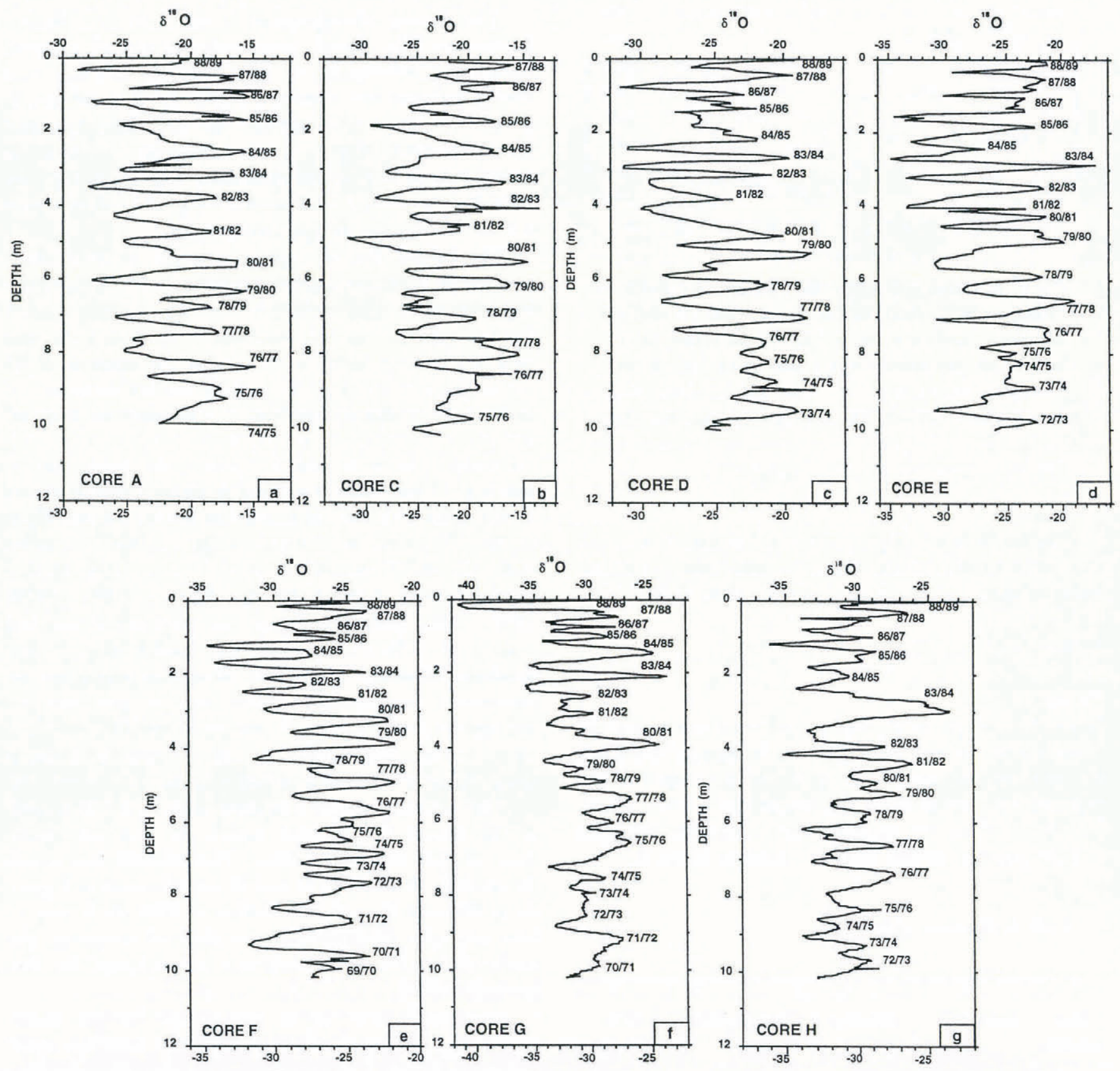

Fig. 6. $a$ and $b$. The $\delta^{18} O$ stratigraphy and the adapted time-scales for cores $A$ and $C$ from Riiser-Larsenisen. $c$ and $d$. $T$ The $\delta^{18} O$ stratigraphy and the adapted time-scales for cores $D$ and $E$ from Ritscherflya. $e$ and $f$. The $\delta^{18} O$ stratigraphy and the adapted time-scales for cores $F$ and $G$ from Ritscherflya. $g$. The $\delta^{18} O$ stratigraphy and the adapted time-scales for core $H$ from Ritscherflya.

anomaly from the mean in each core over the period of 1976-89 was averaged in order to produce a mean accumulation record (Fig. 8). In 1989-90, a year after the firn cores were collected, accumulation stakes at nine of the core locations were measured (Näslund and others, 1991). These stake measurements are used as the 1989 accumulation value.

\section{$\boldsymbol{\beta}$ activity}

The $\beta$-activity profile for core $\mathrm{J}$ is shown together with the oxygen-isotope profile in Figure 9. The stratigraphy suggests that the firn in the lower part of the core was deposited prior to thermonuclear testing. The traditional interpretation for Antarctic snow is that the first increase above background is the 1954-55 surface. Therefore, in this core, this surface is at a depth of $8.8 \mathrm{~m}$. The next peak at $6.5 \mathrm{~m}$ depth should then be the 1964-65 surface. With this interpretation, the 1970-71 peak is not present in the stratigraphy. The other possible interpretation could be that the $6.5 \mathrm{~m}$ peak is the $1970-71$ surface and the previous peak is the one for 1964-65. However, due to the extremely low activity in the lower part of the core, this interpretation is not favoured (personal communication from Dr E. Mosley-Thompson, 1990).

The less-pronounced $\beta$-activity peak for $1954-55$ in this area, compared to records from interior Antarctica (e.g. Petit and others, 1982), is one that has also been recognized by others; coastal stations and stations in the Antarctic Peninsula generally have a weaker 1954-55 level than do the inland stations (Aristarain and others, 1986). 
Table 4. Annual accumulation rates in $\mathrm{cm}$ w.e. for core sites $A, C-H$ and the mean over different 5 year periods based on the $\delta^{18} \mathrm{O}$ stratigraphy

\begin{tabular}{|c|c|c|c|c|c|c|c|}
\hline Year & $A$ & C & $D$ & $E$ & $F$ & $G$ & $H$ \\
\hline $1989^{1}$ & 27.6 & 41.1 & 40.7 & 30.2 & 26.4 & 29.0 & 20.0 \\
\hline 1988 & 18.1 & - & 15.8 & 16.7 & 6.8 & 17.6 & 11.0 \\
\hline 1987 & 16.3 & 19.0 & 23.4 & 38.0 & 24.7 & 11.5 & 28.0 \\
\hline 1986 & 33.6 & 41.1 & 15.9 & 19.8 & 8.0 & 11.8 & 16.2 \\
\hline 1985 & 42.8 & 37.0 & 39.0 & 26.4 & 18.2 & 19.2 & 28.3 \\
\hline 1984 & 33.2 & 43.1 & 28.7 & 21.9 & 19.5 & 30.6 & 47.2 \\
\hline 1983 & 31.4 & 36.1 & 22.6 & 31.4 & 14.8 & 26.4 & 50.0 \\
\hline 1982 & 47.4 & 22.1 & 35.9 & 21.9 & 17.5 & 22.8 & 24.3 \\
\hline 1981 & 45.1 & 53.7 & 53.8 & 10.9 & 28.2 & 41.3 & 28.7 \\
\hline 1980 & 45.0 & 34.5 & 19.9 & 38.2 & 30.4 & 32.7 & 16.9 \\
\hline 1979 & 25.0 & 49.5 & 48.2 & 52.0 & 30.2 & 17.8 & 28.8 \\
\hline 1978 & 42.3 & 57.0 & 52.1 & 36.7 & 22.0 & 25.9 & 49.0 \\
\hline 1977 & 55.6 & 31.1 & 39.7 & 45.1 & 44.9 & 36.1 & 44.1 \\
\hline 1976 & 37.1 & 73.7 & 33.7 & 38.7 & 16.3 & 30.4 & 54.8 \\
\hline 1975 & 59.8 & & 47.7 & 15.9 & 27.9 & 51.9 & 29.1 \\
\hline 1974 & & & 37.8 & 41.9 & 20.3 & 21.8 & 29.4 \\
\hline 1973 & & & & 52.8 & 24.3 & 33.4 & 23.1 \\
\hline 1972 & & & & & 21.1 & 38.7 & \\
\hline 1971 & & & & & 62.2 & 39.2 & \\
\hline 1970 & & & & & 53.3 & & \\
\hline $1976-88$ & 36.4 & 41.5 & 33.0 & 31.1 & 21.7 & 27.6 & 32.9 \\
\hline $1970-74$ & & & & & 36.2 & & \\
\hline $1975-79$ & 43.9 & 52.8 & 44.3 & 37.7 & 28.3 & 33.2 & 41.2 \\
\hline $1980-84$ & 40.4 & 37.9 & 32.2 & 26.3 & 22.0 & 28.2 & 33.4 \\
\hline $1985-88^{2}$ & 27.7 & $32.4^{3}$ & 23.5 & 25.2 & 14.4 & 18.2 & 20.9 \\
\hline Mean all years & 38.0 & 41.5 & 34.3 & 32.2 & 25.8 & 28.9 & 31.8 \\
\hline
\end{tabular}

\footnotetext{
${ }^{1}$ Based on stake measurements.

${ }^{2} 4$ years.

${ }^{3}$ Only 3 years.
}

Based on the $\beta$-activity horizons, the accumulation can be calculated for the time periods 1955-65, 1965-88 and for the whole interval 1955-88 (Table 5).

\section{DISCUSSION}

\section{Spatial variations in surface accumulation}

Stake measurements show a large variability in accumulation over short distances (Fig. 4). The 1988 accumulation measurements from Ritscherflya show a standard deviation of $70 \%$. Some of the variations are most likely an effect of differences in the slope of the longwave dunes, visible on satellite images, whilst others are due to sastrugi. The large spatial variability invokes the use of smoothing to reveal the overall pattern. The smoothed record of stake measurements shows that the accumulation decreases inland, at least up to about $300 \mathrm{~km}$ from the coast. This is expected, since precipitation and accumulation are functions of temperature, elevation and distance from the moisture source (Muszynski and Birchfield, 1985; Giovinetto and others, 1990). Superimposed on this overall pattern are other small differences in surface accumulation. A slight decrease in accumulation is evident in the grounding-line area on RiiserLarsenisen. This change in accumulation is in accord with previous work in the same area (Gjessing and Wold, 1986) as well as on the Brunt Ice Shelf (Thomas, 1973). A likely explanation is the steeper surface slope in the area of the grounding line (Thomas, 1973). Stakes closer than about $20 \mathrm{~km}$ from the coastline show a lower accumulation rate than stakes farther inland on the ice shelf. A slight decrease of snow accumulation in a $4-5 \mathrm{~km}$ wide area on the outer edge of the ice shelf has also been observed on the Brunt Ice Shelf (Thomas, 1973) and on the ice shelf seaward of Maudheim (Swithinbank 1957). This is most likely due to increased wind scouring in the zone closest to the coast. An accumulation minimum also occurs around $250 \mathrm{~km}$ from the coast, in an area without any major differences in either elevation or slope. It is possible that this minimum is caused by increasing wind 

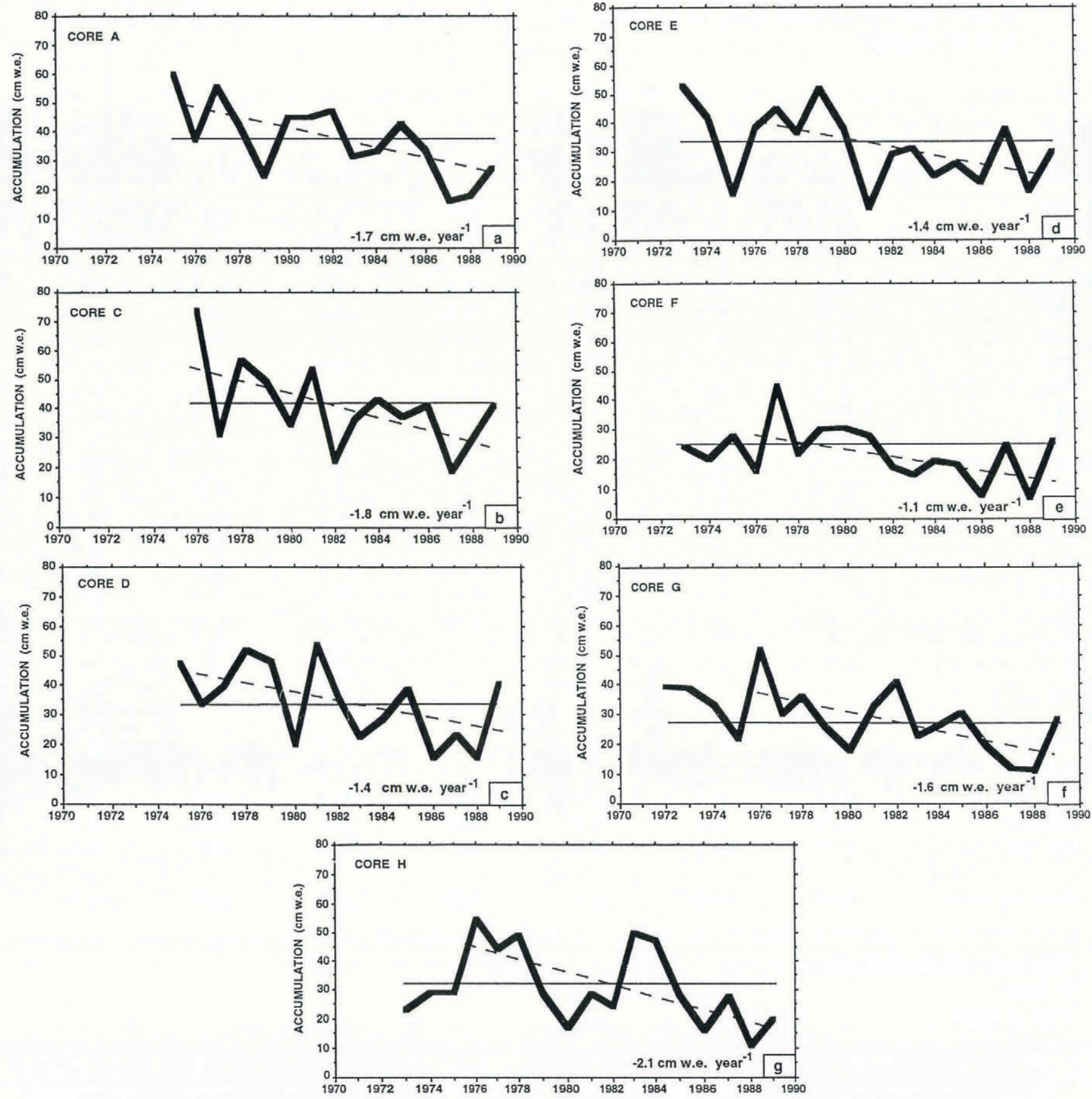

Fig. 7. a-g. The mean annual accumulation variations, obtained from oxygen-isotope stratigraphy and 1 year of stake measurements (1989). The thin line is the mean for all years in each core. The dashed line is the regression line for 197689 (the period covered in all cores), and the number below is the annual accumulation decrease during this period.

scouring due to wind channelling in the vicinity of the Heimefrontfjella mountain range. However, a similar phenomenon has been observed along a traverse inland from Mirny, where there are no nunataks (Young and others, 1982). Because the Antarctic surface-wind patterns are still relatively unknown (Parish, 1988), we leave this subject without further speculation. Over the final $50 \mathrm{~km}$ of the stake traverse, just before Heimefrontfjella, the accumulation again shows a slight increase. At this point, it is difficult to say whether this is an effect of the mountain range or whether it is part of the largerscale distribution of surface accumulation.

Despite the fact that the accumulation rate for 1989 is more than $100 \%$ higher than for 1988, the spatial distribution is maintained with a very high degree of coherence (Fig. 5). Similar results about the coherence in the spatial pattern were obtained by Young and others (1982) for stake traverses in the Vostok and Dome C areas.

Some of the stakes show a negative accumulation; $3.8 \%$ of the stakes show a negative accumulation value for the 1988 accumulation year and $0.3 \%$ for 1989 . The negative accumulation value is only a few centimetres for most of these stakes (the largest negative value is $-7 \mathrm{~cm}$ for one stake during 1988). Interestingly, during our field work in the area in 1988-89, we were able to follow the vehicle tracks from the previous year over long distances. There are several possible explanations for the low accumulation: measurement error, snow compaction, sublimation or wind-scouring. Because most of the stakes 
Isaksson and Karlén: Patterns in snow accumulation, western Dronning Maud Land, Antarctica

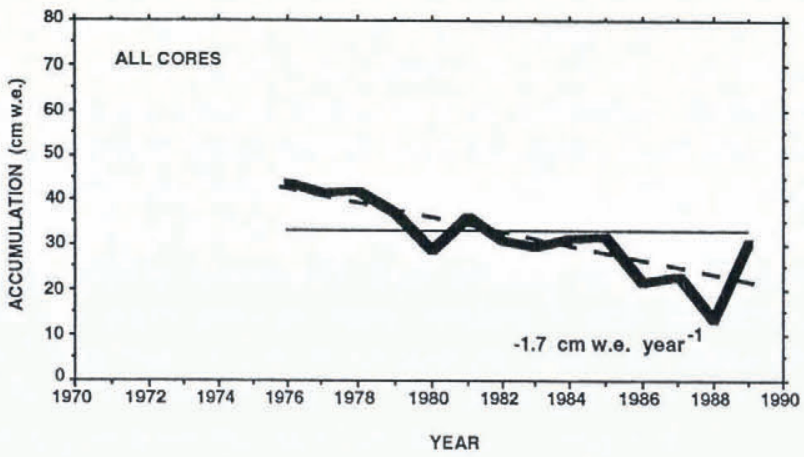

Fig. 8. The 1976-89 mean annual accumulation variations, obtained from seven firn cores and 1 year of stake measurements (1989). The thin line is the mean for all years and the dashed line is the regression line and the number below is the annual accumulation decrease during this period.

with negative accumulation are in the low-accumulation area around $200 \mathrm{~km}$ from the coast, wind-scouring seems to be the most likely explanation.

\section{Temporal variations in net accumulation}

2 years' stake measurements show that, in addition to a high spatial variability, there is also a large temporal variability (Fig. 5). Furthermore, the net-balance records from the oxygen-isotope stratigraphy show a considerable inter-annual variability - up to several hundred per cent (Fig. 7a-g). Therefore, it is obvious that several years of accumulation measurements are necessary to produce a reliable estimate of the net accumulation; shorter periods are far too influenced by annual variations in precipitation and spatial variations. It has been suggested that a period of 10 years is sufficient when using an accumulation record from one site for regional purposes (Morgan, 1985; Mosley-Thompson and others, 1985).

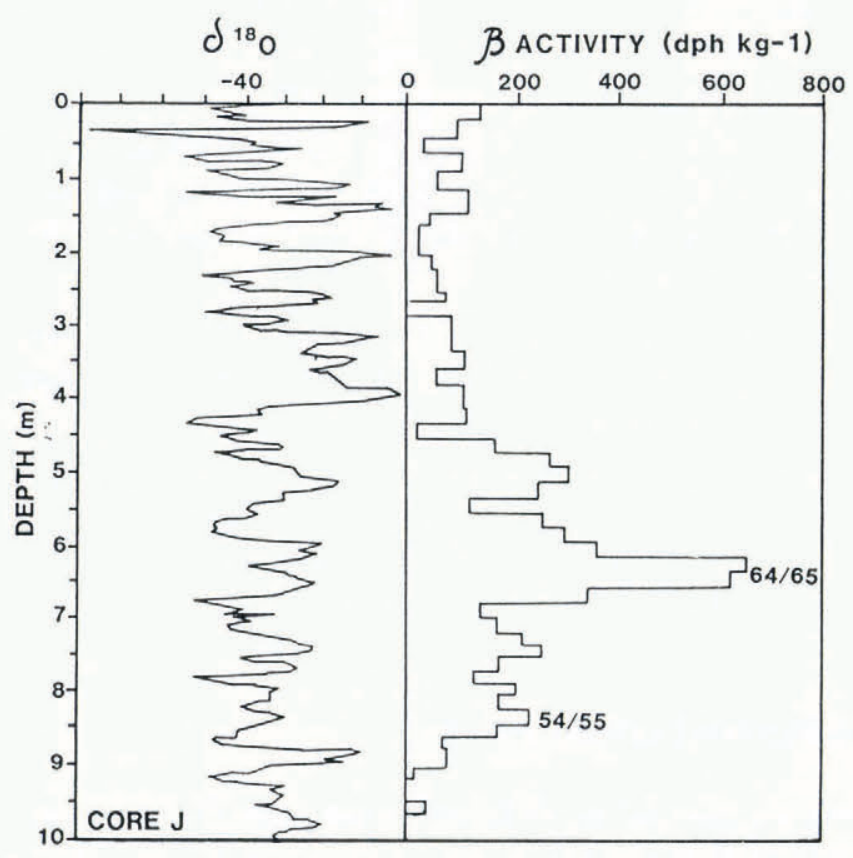

Fig. 9. $\delta^{18} \mathrm{O}$ record and the $\beta$-activity profile for core $\mathcal{J}$ from Amundsenisen.
Table 5. Mean annual accumulation data for firn core $\mathcal{J}$ on Amundsenisen based on the $\beta$-activity stratigraphy

\begin{tabular}{ccc}
\hline Period & $\begin{array}{c}\text { Accumulation per year } \\
\text { cm w.e. }\end{array}$ & $\begin{array}{c}\text { Mean density } \\
\mathrm{kg} \mathrm{m}^{-3}\end{array}$ \\
& & \\
\hline $1955-64$ & 10.2 & 443 \\
$1965-88$ & 10.1 & 372 \\
$1955-88$ & 10.4 & 400 \\
\hline
\end{tabular}

The temporal variability in accumulation shows a common pattern for many of the cores. All of the cores from the ice shelf and Ritscherflya show a decreasing accumulation trend during the period of 1976-89 (Fig. $7 \mathrm{a}-\mathrm{g})$. Linear-regression analysis on these accumulation records suggests a $1.4-2.1 \mathrm{~cm}$ w.e. annual decrease during this period. What caused this trend? Because it has previously been found that the precipitation rate over Antarctica is strongly correlated with temperature, it is interesting to compare the obtained accumulation record to the Halley temperature record. The Halley temperature record is preferred to the SANAE record, because it is longer. Indeed, a temperature decrease of about $1^{\circ} \mathrm{C}$ has been recorded at Halley during the time covered by the accumulation record (Fig. 3). Considering the distance between Halley and western Dronning Maud Land, the temperature and the accumulation records show surprisingly similar trends (Fig. 10). However, the inter-annual correlation is not striking, but the overall patterns, which probably reflect the climatic signal filtered from any local weather patterns.

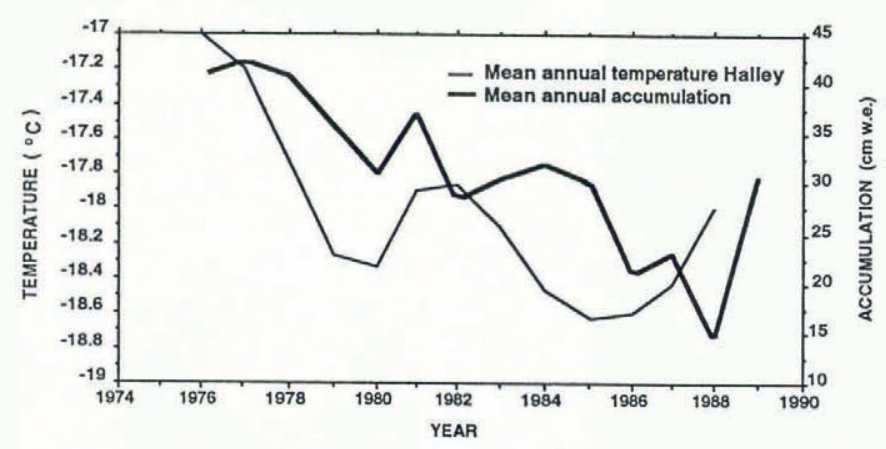

Fig. 10. Mean annual accumulation, 1976-89, obtained from firn cores and 1 year of stake measurements (1989), and mean annual temperature at Halley for the same period.

The net accumulation at Riiser-Larsenisen of $39.0 \mathrm{~cm}$ w.e. (Table 3), obtained from two firn cores covering the 1976-88 period, is in agreement with results from Orheim and others (1986), although the data are for 1957-78. Assuming that these two data sets are of equal quality, they can be combined to a single data set covering the 1957-88 period. Only one year of measurements, 1978, overlaps and the means from both are used in the compilation. Hence, the total mean accumulation for this combined period is $34.7 \mathrm{~cm}$ w.e. This 31 year long accumulation 


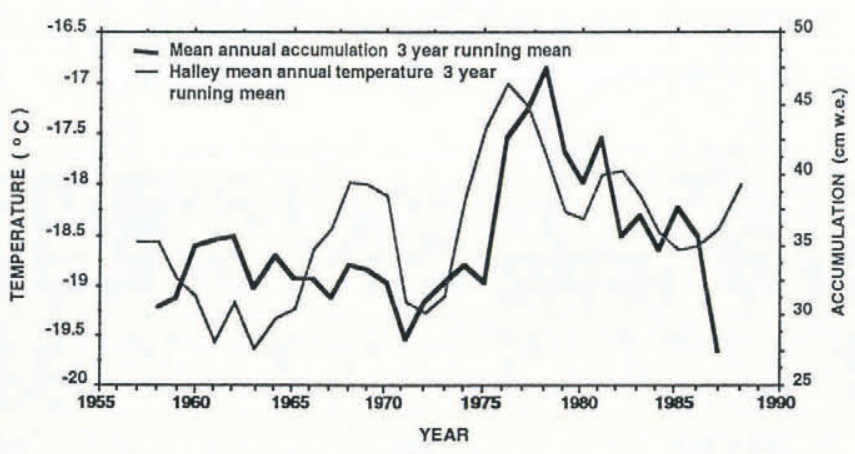

Fig. 11. Accumulation record from Riiser-Larsenisen, 1958-87, compared with the mean annual temperature record from Halley, 1957-89. Both records are 3 year running means.

record suggests an increase in the late 1970s and a decrease after (Fig. 11). The temperature record from Halley during the same time does suggest that these changes can be related to climatic changes. Looking at the graph with the 3 year running mean of the Halley temperature record and the Riiser-Larsenisen accumul-ation record (Fig. 11), it is striking that the positive accumulation anomaly, starting around 1975, cor-responds quite well to a warm period at Halley. The 1973-75 temperature increase of about $2{ }^{\circ} \mathrm{C}$ at Halley is contemporaneous with a $50 \%$ increase in accumulation at Riiser-Larsenisen which is somewhat higher than a precipitation increase of 5$20 \% \mathrm{~K}^{-1}$ given in a compil-ation by Robin (1977). It is very likely that this accumulation increase was caused by other factors, such as changes in the storm tracks, less wind-scouring, etc. Unfortunately, there is a lack of highresolution accumul-ation records from other parts of Antarctica which could confirm these changes. However, increased accumulation rates have been presented by Morgan and others (1991) from Wilkes Land.

The accumulation changes farther inland on Amundsenisen are based on a single core $\mathrm{J}$, and the $\beta$-activity measurements do not (Fig. 9) suggest any large changes in surface accumulation since 1955 (Table 5). Using the 1954-55 and 1964-65 $\beta$-activity surfaces at Dome C, Petit and others (1982) found $30 \%$ higher accumulation for the period 1965-79 compared to 1955-65, and similarly at the South Pole (Jouzel and others, 1983). If this change in accumulation is detectable in the interior parts of Antarctica, where the accumulation is less than in the relatively coastal area of Dronning Maud Land, such a change should also be readily found in our record. Because of indications of decoupling of the climate between different parts of Antarctica (e.g. Raper and others, 1984), there is a possibility that changes in snow accumulation are also different. Another possibility is that, because the core from our field area spans an additional decade, 1980, the decreasing accumulation trend that we can see in the firn-core record from RiiserLarsenisen and Ritscherflya can negate the accumulation increase that occurred during 1970. Finally, one has to emphasize that our data are only based on this single core with all the uncertainties that come with it.

The lack of high-resolution accumulation records covering the same time period as this work makes it difficult to say whether the temporal changes in accumulation apparent in this part of Dronning Maud Land are local or occurred over larger areas of the Antarctic continent; as mentioned, similar results have recently been presented from Wilkes Land (Morgan and others, 1991). This has implications when calculating the mass balance for Antarctica. In the latest mass-balance compilation by Bentley and Giovinetto (1990), they concluded that a positive mass balance exists for the Antarctic ice sheet, equivalent to $0.2-1.1 \mathrm{~mm}^{-1}$ year $^{-1}$ of sea-level lowering. However, the area where SWEDARP is active is a part of one of the drainage systems (called $\mathrm{KK}^{\prime}$ ), where they suggest a negative mass balance. The reason for this is that the melt rates beneath the ice shelf have been found to be higher than that required to maintain a steady-state condition (Thomas, 1973; Gjessing and Wold, 1986). Bentley and Giovinetto (1991) further used the positive mass balance in a nearby drainage system in Dronning Maud Land (called $\mathrm{AA}^{\prime}$ ) as an example of the accuracy of their mass-balance estimates. This drainage system lacks any major ice streams or other outflow systems and it has mountain ranges which dam the interior ice flow; a positive mass balance is therefore easy to visualize. The total mass balance of this drainage area is currently being worked out and will be presented by Holmlund and others. However, as long as large parts of Antarctica lack field data, such as the now-mentioned areas, we can only speculate about the total mass balance.

\section{CONCLUSIONS}

(1) The mean annual accumulation for the period 197688 is about 0.4 mw.e. for Riiser-Larsenisen and about $0.3 \mathrm{~m}$ w.e. for Ritscherflya. Data from one core from Amundsenisen, at $3000 \mathrm{~m}$ a.s.l., suggest a mean annual accumulation of $0.1 \mathrm{~m}$ w.e. for $1955-88$.

(2) The spatial variations in accumulation are large over short distances. A decreasing accumulation rate from the coast and up to $300 \mathrm{~km}$ inland is visible in the stake measurements. Superimposed on the overall pattern are smaller-scale variations in accumulation, probably due to the local topography and slope changes.

(3) Despite large year-to-year variations in the accumulation, all firn-core records from Riiser-Larsenisen and Ritscherflya show a decreasing trend in accumulation between 1976 and 1988.

(4) The accumulation records covering 1957-88 indicate an increase in accumulation by $12 \%$ from the period $1957-74$ to $1975-88$.

(5) Accumulation variations that took place at RiiserLarsenisen and Ritscherflya between 1957 and 1988 suggest a relationship with temperature variations recorded at Halley during the same time.

\section{ACKNOWLEDGEMENTS}

We are grateful to SWEDARP and Saab Helicopter for making it possible for us to conduct the field work on which this paper is based. Dr M. Seppälä, Mr J.-O. Näslund, Mr V. Pohjola and Mr A Stroeven helped us 
with the field work. Dr W. Dansgaard provided the oxygen-isotope analysis and Dr E. Mosley-Thompson provided the $\beta$-activity analysis. The following people gave valuable suggestions at different stages in the preparation of this paper: Dr T. Hughes, Dr M. Prentice, Dr J. Fastook, Dr J. Kohler, Dr G. Rosquist and Dr C. Bronge. Mr H. Drake drew the maps and some of the illustrations. Financial support came from The Swedish National Council.

\section{REFERENGES}

AlDahan, A. A., G. Possnert, E. Isaksson and W. Karlén. 1990. Advances in chemical separation of cosmogenically produced ${ }^{10} \mathrm{Be}$ radionuclide from ice. Uppsala, Uppsala University. The Svedenberg Laboratory and Department of Radiation Sciences. (Report TSL/ISV-90-0046.)

Aristarain, A.J., J. Jouzel and M. Pourchet. 1986. Past Antarctic Peninsula climate (1850-1980) deduced from an ice core isotope record. Climatic Change, 8(1), 69-89.

Bentley, C. R. and M. B. Giovinetto. 1991. Mass balance of Antarctica and sea level change. In Weller, G., C. L. Wilson and S. A. B. Severin, eds. International Conference on the Role of the Polar Regions in Global Change. Proceedings of a conference held June 11-15, 1990 at the University of Alaska Fairbanks. Vol. 2. Fairbanks, AK, University of Alaska, 481488.

Dansgaard, W., S. J. Johnsen, H. B. Clausen and N. Gundestrup. 1973. Stable isotope glaciology. Medd. Grönl., 197(2).

Drewry, D.J., ed. 1983. Antarctica: glaciological and geophysical folio. Cambridge, University of Cambridge. Scott Polar Research Institute.

Giovinetto, M. B., N. M. Waters and C. R. Bentley. 1990. Dependence of Antarctic surface mass balance on temperature, elevation, and distance to open water. J. Geophys. Res., 95(D4), 3517-3531.

Gjessing, Y. and B. Wold. 1986. Absolute movements, mass balance and snow temperatures of the Riiser-Larsenisen Ice Shelf, Antarctica. Nor. Polarinst. Skr. 187, 23-31.

Holmlund, P., E. Isaksson and W. Karlén. 1989. Massbalans, isrörelse och isdynamik. Stockholm, Stockholms Universitet. Naturgeografiska Institutionen. (Forskningsrapport 73.)

Hoppe, H. and F. Thyssen. 1988. Ice thickness and bedrock elevation in western Neuschwabenland and Berkner Island, Antarctica. Ann. Glaciol., 11, 42-45.

International Atomic Energy Agency. 1975. Environmental isotope data No. 5. World survey of isotope concentration in precipitation (1970-1971). Vienna, International Atomic Energy Agency. (Technical Report Series 165.)

International Atomic Energy Agency. 1979. Environmental isotope data No. 6. World survey of isotope concentration in precipitation (1972-1975). Vienna, International Atomic Energy Agency. (Technical Report Series 192.)

International Atomic Energy Agency. 1984. Environmental isotope data No. 8. World survey of isotope concentration in precipitation (1976-1983). Vienna, International Atomic Energy Agency. (Technical Report Series 226.)

International Atomic Energy Agency. 1990. Environmental isotope data No. 9. World survey of isotope concentration in precipitation (1984-1987) Vienna, International Atomic Energy Agency. (Technical Report Series 311.)

Jones, P.D. and D.W.S. Limbert. 1987. A data bank of Antarctic temperature and pressure data. Washington, DC, U.S. Department of Energy. Carbon Dioxide Research Division. (Publication TRO 38.)

Jouzel, J., L. Merlivat, J.R. Petit and C. Lorius. 1983. Climatic information over the last century deduced from a detailed isotopic record in the South Pole snow. F. Geophys. Res., 88(C4), 2693-2703.

Koci, B. R. and K. C. Kuivinen. 1984. The PICO lightweight coring auger. J. Glaciol., 30(105), 244-245.

Loewe, F. 1970. Screen temperatures and $10 \mathrm{~m}$ temperatures. F. Glaciol., 9(56), 263-268.

Lorius, C. 1983. Accumulation rate measurements on cold polar glaciers. In Robin, G. de Q, ed. The climatic record in polar ice sheets. Cambridge, etc., Cambridge University Press, 65-70.
Lunde, T. 1961. On the snow accumulation in Dronning Maud Land. Nor. Polarinst. Skr. 123.

Morgan, V.I. 1985. An oxygen isotope-climate record from the Law Dome, Antarctica. Climatic Change, 7(4), 415-426.

Morgan, V. I., I.D. Goodwin, D. M. Etheridge and C. W. Wookey. 1991. Evidence from Antarctic ice cores for recent increases in snow accumulation. Nature, 354(6348), 58-60.

Mosley-Thompson, E., P. D. Kruss, L. G. Thompson, M. Pourchet and P. Grootes. 1985. Snow stratigraphic record at South Pole: potential for paleoclimatic reconstruction. Ann. Glaciol., 7, 26-33.

Muszynski, I. and G. E. Birchfield. 1985. The dependence of Antarctic accumulation rates on surface temperature and elevation. Tellus, 37A, 204-208.

Näslund, J. -O., V. Pohjola and A. Stroeven. 1991. Glaciological surveys in Vestfjella and Heimefrontfjella, Dronning Maud Land, Antarctica, 1989| 1990. Stockholm, Stockholms Universitet. Naturgeografiska Institutionen. (Forskningsrapport 83.)

Oerlemans, J. 1982. Response of the Antarctic ice sheet to a climatic warming: a model study. 7. Climatol., 2(1), 1-11.

Oerlemans, J. and C.J. van der Veen. 1984. Ice sheets and climate. Dordrecht, etc., D. Reidel Publishing Company.

Orheim, O. and 6 others. 1986. Oxygen isotopes and accumulation rates at Riiser-Larsenisen, Antarctica. Nor. Polarinst. Skr. 187, 33-47.

Ostrem, G. and A. Stanley. 1969. Glacier mass balance measurements - a manual for field and office work. Ottawa, The Canadian Department of Energy, Mines and Resources; Oslo, The Norwegian Water Resources and Electricity Board.

Parish, T. R. 1988. Surface winds over the Antarctic continent: a review. Rev. Geophys., 26(1), 169-180.

Parish, T. R. and D. H. Bromwich. 1987. The surface windfield over the Antarctic ice sheets. Nature, 328(6125), 51-54.

Peel, D. A. and H.B. Clausen. 1982. Oxygen-isotope and total betaradioactivity measurements on $10 \mathrm{~m}$ ice cores from the Antarctic Peninsula. 7. Glaciol., 28(98), 43-55.

Petit, J. R., J. Jouzel, M. Pourchet and L. Merlivat. 1982. A detailed study of snow accumulation and stable isotope content in Dome C (Antarctica). 7. Geophys. Res., 87(C6), 4301-4308.

Raper, S. C. B., P. R. Mayes, P. D. Jones and M.J. Salinger. 1984. Variations in the surface air temperatures. Part 3. The Antarctic, 1957-82. Mon. Weather Rev., 108, 1362-1369.

Reinwarth, O., W. Rauert, W. Stichler and H. Moser. 1982. Preliminary investigations on accumulation at the Filchner/Ronne ice shelves and Atka Bay. Ann. Glaciol., 3, 274-278.

Reinwarth, O., W. Graf, W. Stichler, H. Moser and H. Oerter. 1985. Investigations of the oxygen-18 content of samples from snow pits and ice cores from the Filchner-Ronne Ice Shelves and Ekström Ice Shelf. Ann. Glaciol., 7, 49-53.

Repp, K. 1978. Snow accumulation and snow stratigraphy on RiiserLarsenisen, Dronning Maud Land, Antarctica. Nor. Polarinst. Skr. $169,81-92$.

Robin, G.de Q. 1977. Ice cores and climatic change. Philos. Trans. $R$. Soc. London, Ser. B, 280, 143-168.

Robin, G. de Q. 1988. The Antarctic ice sheet, its history and response to sea level and climatic changes over the past 100 million years. Palaeogeogr. Palaeoclimatol. Palaeoecol., 67, 31-50.

Schytt, V. 1958. Glaciology II. Snow and ice temperatures in Dronning Maud Land. Norwegian-British-Swedish Antarctic Expedition, 1949-52. Sci. Results, IV, 153-179.

Swithinbank, C. 1957. Glaciology I. The morphology of the ice shelves of western Dronning Maud Land. Norwegian-British-Swedish Antarctic Expedition, 1949-52. Sci. Results, III, 1-37.

Swithinbank, C. 1962. Maudheim revisited: the morphology and regime of the ice shelf, 1959-60. Nor. Polarinst. Arbok 1960, 28-31.

Thomas, R. H. 1973. The dynamics of the Brunt Ice Shelf, Coats land, Antarctica. Br. Antarct. Surv. Sci. Rep. 79.

Whillans, I. M. and R.A. Bindschadler. 1988. Mass balance of Ice Stream B, West Antarctica. Ann. Glaciol., 11, 187-193.

Young, N. W., M. Pourchet, V. M. Kotlyakov, P. A. Korolev and M. B. Dyugerov. 1982. Accumulation distribution in the IAGP area, Antarctica: $90^{\circ} \mathrm{E}-150^{\circ} \mathrm{E}$. Ann. Glaciol., 3, 333-338.

Zwally, H.J. 1989. Growth of Greenland ice sheet: interpretation. Science, 246(4937), 1589-1591.

The accuracy of references in the text and in this list is the responsibility of the authors, to whom queries should be addressed. 